\title{
The Determination of Pertechnetate and Non-Pertechnetate Species in Hanford Tanks -- Phase 1
}

Authors

J. B. Duncan

Washington River Protection Systems LLC

S. A. Catlow

Advanced Technologies and Laboratories International, Inc.

Date Published

February 2014

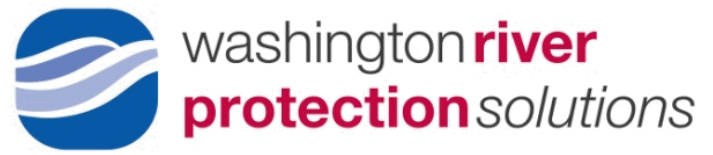

Prepared for the U.S. Department of Energy

Office of River Protection

Contract No. DE-AC27-08RV14800 
TRADEMARK DISCLAIMER

Reference herein to any specific commercial product, process,

or service by trade name, trademark, manufacturer, or

otherwise, does not necessarily constitute or imply its

endorsement, recommendation, or favoring by the United

States Government or any agency thereof or its contractors or subcontractors.

This report has been reproduced from the best available copy.

Printed in the United States of America 


\section{EXECUTIVE SUMMARY}

An analytical method is required to distinguish between the pertechnetate and non-pertechnetate forms of technetium; currently, the methods available only report the total technetium present in a sample. The overall objective of this effort is to develop a method for routinely analyzing Hanford tank waste for technetium in the pertechnetate and the non-pertechnetate forms. A phased approach will be deployed to accomplish this objective.

Phase I Comparison of existing technetium analysis methods with modification Phase II Demonstration of modified methods using non-pertechnetate spiked simulants Phase III Demonstration of chosen method on Hanford tank sample containing non-pertechnetate

This report describes the Phase I work, providing a comparison of Aliquat 336 and TEVA ${ }^{\circledR 1}$ in the removal of pertechnetate and discussing the subsequent analysis for technetium in both alkaline and acidic environments without oxidation. The effort was executed under LAB-PLN-13-00004, The Determination of Pertechnetate and Non-Pertechnetate Species in Hanford Tanks Phase I.

The presence of non-pertechnetate species in Hanford tank waste has been postulated by several studies. Two procedures are routinely used for analysis of technetium in Hanford tank samples, neither of which provides a determination of the non-pertechnetate species; and due to incorporation of acidification and oxidation steps, the methods may actually convert any nonpertechnetate technetium present in the sample to pertechnetate.

One of the laboratory procedures LA-438-114, "Determination of Technetium-99 by Extraction with TEVA ${ }^{\circledR}$ Resin," adjusts the $\mathrm{pH}$ between 7 and 12 with $1 \mathrm{M}$ nitric acid prior to extraction with TEVA ${ }^{\circledR}$ Resin. The other procedure LA-438-101, "Determination of Technetium-99 by Solvent Extraction" uses solvent extraction prior to binding with Aliquat ${ }^{\circledR 2} 336$. In this method, the sample undergoes oxidation with peroxide to convert any non-pertechnetate to pertechnetate followed by nitric acid and sodium hydroxide washes. In both methods, liquid scintillation is employed for radiological counting.

In Phase I of this effort, it appears that both Aliquat ${ }^{\circledR 2} 336$ and TEVA ${ }^{\circledR}$ Resin extract pertechnetate either directly from the highly alkaline sample or from the sample after acidification. The TEVA ${ }^{\circledR}$ Resin exhibited less error than did the Aliquat ${ }^{\circledR} 336$ extraction. In the extraction using TEVA ${ }^{\circledR}$ Resin in the highly alkaline solution, the sample was not subjected to oxidation as occurred with the Aliquat ${ }^{\circledR} 336$. When using Aliquat ${ }^{\circledR} 336$, the vortex step used to partition the pertechnetate into the organic will oxidize non-pertechnetate. It also appeared that the pertechnetate largely remained bound to the Aliquat ${ }^{\circledR} 336$ and did not readily extract into the acid and base washes.

The relative percent difference between the Aliquat ${ }^{\circledR} 336$ and the TEVA ${ }^{\circledR}$ Resin is $8.1 \%$. If the spike is considered to be a true value $(1.7447 \mathrm{E} 04 \mathrm{dpm} / \mathrm{mL})$, then the percent of error is $13.6 \%$

${ }^{1}$ TEVA is a registered trademark of Eichrom Technologies, Inc., Lisle, Illinois.

${ }^{2}$ Aliquat 336 is a registered trademark of BASF, Ludwigshafen, Germany. 
and $6.35 \%$, respectively (Table ES-1). The TEVA ${ }^{\circledR}$ Resin exhibited less error than did the Aliquat ${ }^{\circledR} 336$ extraction.

Table ES-1. Results of Aliquat ${ }^{\circledR} 336$ Extraction and TEVA ${ }^{\circledR}$ Resin.

\begin{tabular}{|l|c|c|c|c|}
\hline \multicolumn{1}{|c|}{ Sample Number } & Matrix & $\mathbf{d p m} / \mathbf{m L}$ & $\begin{array}{c}\text { Relative \% } \\
\text { Difference }\end{array}$ & Error (\%) \\
\hline S13R000511 & Aliquat $^{(\mathbb{B}} 336$ & 15,074 & & 13.6 \\
\hline S13R000511 & TEVA $^{\mathbb{B}}$ Resin & 16,339 & 8.1 & 6.35 \\
\hline
\end{tabular}

The primary conclusion from this effort is that the TEVA ${ }^{\circledR}$ Resin works under very alkaline conditions and is a candidate for further study in the attempt to delineate non-pertechnetate technetium from pertechnetate technetium.

For a future effort, it is suggested that other valence states of technetium be employed along with pertechnetate in a simple simulant. For example, in alkaline $\mathrm{pH}$, reducing sugars will auto reduce pertechnetate to Tc (IV/V) with the sugar as the ligand. The sugar D-threose will convert approximately $98 \%$ of Tc (VII) to the Tc (IV/V) state. ("The autoreduction of pertechnetate in aqueous, alkaline solutions," [D. E. Berning et al. 2005]). A second method to reduce Tc (VII) to a lower valence state is mixing with hydroxylamine in an alkaline solution. The resulting reduced technetium species would be with and without an organic ligand.

The pertechnetate and reduced technetium species would then be subjected to extraction by Aliquat $^{\circledR} 336$ and TEVA ${ }^{\circledR}$ Resin and analysis using inductively coupled plasma-mass spectrometry. The effort would be focused on the partitioning of the technetium species and the total concentration of mass 99 using the inductively coupled plasma-mass spectrometry with a collision cell to ensure molecules are analyzed in their atomic units. 


\section{Table of Contents}

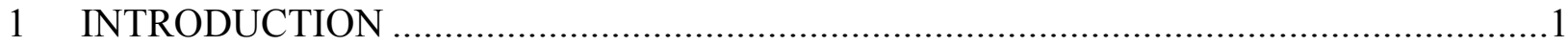

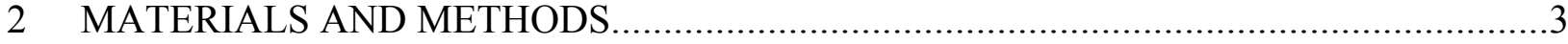

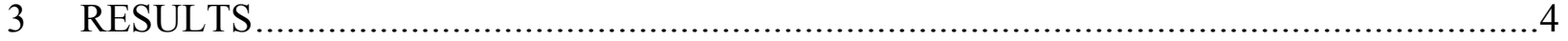

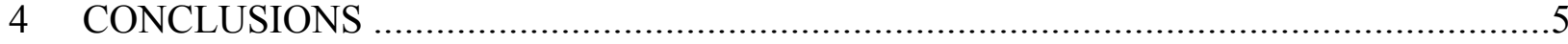

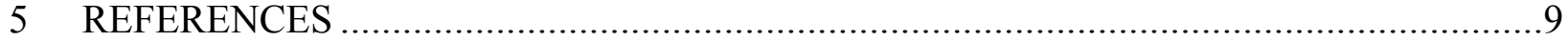

\section{List of Tables}

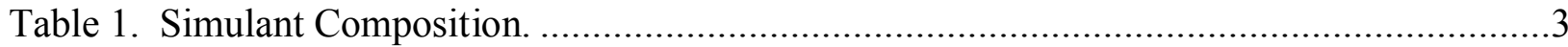

Table 2. Results from the Analyses of Aliquat ${ }^{\circledR} 336$ from Acid-Side Extraction. .......................

Table 3. Results from the Analyses of Base-Side Extractions. ...................................................

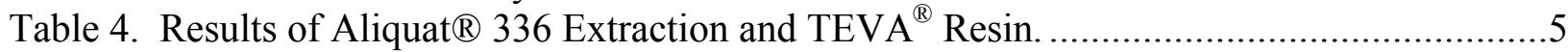

Table 5. Percent Error as a Function of Spike Concentration. .....................................................

\section{List of Figures}

Figure 1. Current ATL Laboratory Methods for Technetium Determination. .............................2

Figure 2. Technetium Determination Method Comparison Testing..............................................

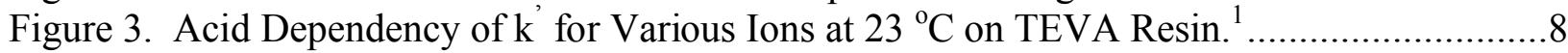

\section{List of Terms}

\section{Acronyms and Abbreviations}

ATL Advanced Technologies and Laboratories International, Inc.

ICP-MS inductively coupled plasma-mass spectrometry

LSC liquid scintillation count(ing)

SBD sample breakdown diagram

RCRA Resource Conservation and Recovery Act

\section{Units}

dpm disintegrations per minute

$\mu \mathrm{Ci} \quad$ microcurie

M molar

$\mathrm{mL} \quad$ milliliter 


\section{INTRODUCTION}

The presence of non-pertechnetate species in Hanford tank waste has been identified by several studies. For example, work by Schroeder, et al. (LA-UR-95-4440, Technetium Partitioning for the Hanford Tank Waste Remediation System: Anion Exchange Studies for Partitioning Technetium from Synthetic DSSF and DSS Simulants and Actual Hanford Wastes (101-SY and 103-SY) Using Reillex-HPQ Resin) indicated that tank 241-SY-101 and tank 241-SY-103 contained $37 \%$ and $30 \%$ of the technetium as the pertechnetate species, leaving $63 \%$ and $70 \%$ as non-pertechnetate species, respectively. The most mature technetium removal technologies (e.g., ion exchange) are specific for the pertechnetate anion, and any technetium present in a different form will not be removed. The ability to quantify the amount of non-pertechnetate present in Hanford Tank samples is essential to the development of an effective technetium removal process.

Notes are located in lab book HNF-274-3, page 43. All other records, such as the waste stream fact sheets, job hazard analysis, radiation control check sheet, and laboratory analytical data are contained in the project files.

This report contains information gathered in the first phase of a multi-phased approach to delineate a method or methods to yield an accurate estimate of the amount of non-pertechnetate in the Hanford tank waste.

The objective of Phase 1 is to compare the effectiveness of Aliquat ${ }^{\circledR} 336$ and TEVA ${ }^{\circledR}$ sorbent (solid phase with Aliquat ${ }^{\circledR} 336$ coating) in their ability to remove pertechnetate from an acidic and basic simple simulant without oxidation. Aliquot $336^{\mathbb{B}}$ is tricapryl-methyl ammonium nitrate quaternary ammonium salt which extracts technetium with an anion exchange mechanism ("Extraction behaviour of technetium and actinides in the Aliquat-336/nitric acid system," [Landgren and Lilgenzin 1999]).

To meet the objective of differentiating between pertechnetate and non-pertechnetate species, there are a number of issues associated with the current Advanced Technologies and Laboratories International, Inc. (ATL) methods for determining technetium (see Figure 1). 
Figure 1. Current ATL Laboratory Methods for Technetium Determination.

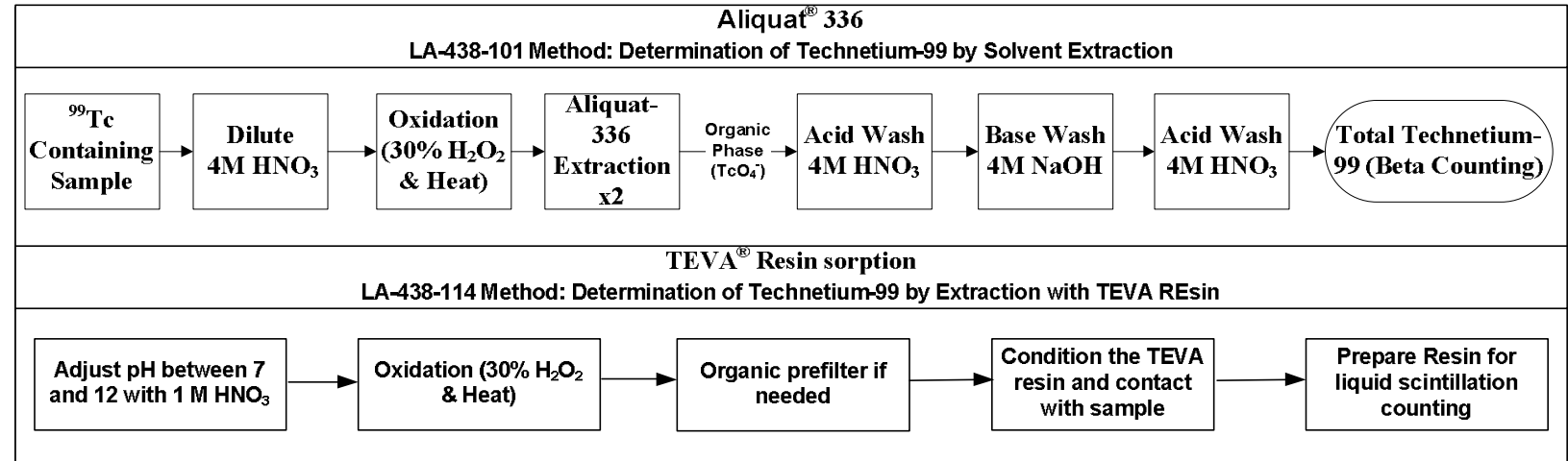

1. The oxidation step $\left(30 \% \mathrm{H}_{2} \mathrm{O}_{2}\right.$ and heat) is included specifically to convert any nonpertechnetate to the pertechnetate form.

2. The acidification with nitric acid may have an oxidizing effect and also convert some or all of the non-pertechnetate to pertechnetate.

The effect of omitting these steps from either method is not known. The first phase of development of a viable non-pertechnetate analysis method is to compare modified versions (no acidification or oxidation) of the current ATL technetium determination methods to ascertain the impact these changes may have on the recovery of technetium from a spiked simple simulant. The modified methods are shown in Figure 2. 
Figure 2. Technetium Determination Method Comparison Testing.

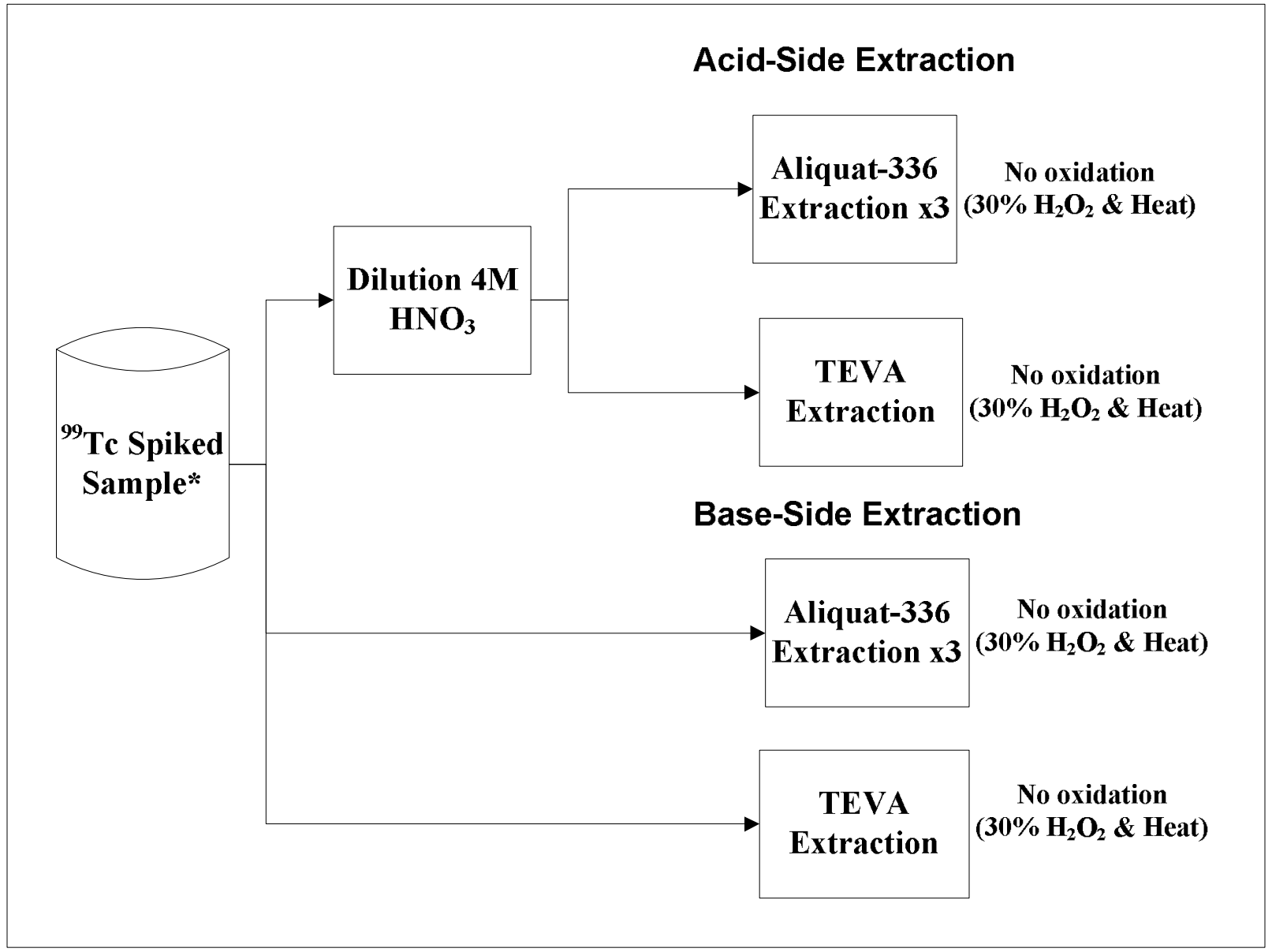

\section{MATERIALS AND METHODS}

A simple tank simulant was formulated as shown in Table 1.

Table 1. Simulant Composition.

\begin{tabular}{|l|c|}
\hline \multicolumn{1}{|c|}{ Reagent } & Concentration \\
\hline Sodium hydroxide & $1 \mathrm{M}$ \\
\hline Sodium nitrate & $2 \mathrm{M}$ \\
\hline Sodium nitrite & $1 \mathrm{M}$ \\
\hline
\end{tabular}

The simulant was spiked with a known amount of pertechnetate, $54,000 \mathrm{dpm}$ or $0.0245 \mu \mathrm{Ci} / \mathrm{mL}$. The spike was $5 \mathrm{~mL}$ of pertechnetate to $10 \mathrm{~mL}$ of simulant. The sample breakdown diagrams (SBD) are shown in Appendix A. 
Since the stock simulant solution used to cascade each of the SBD sections was made from the same container of non-spiked composition, and since the pertechnetate spike was introduced at the same volume from the same source, it was decided to submit only S13R000499 for analysis. The expected count for the spiked simulant was $18,000 \mathrm{dpm}$.

For the acid-side extraction, the simulant was diluted in $10 \mathrm{~mL}$ of $4 \mathrm{M}$ nitric acid; an aliquot was extracted with TEVA ${ }^{\circledR}$ resin, and the remainder was extracted three times with Aliquat ${ }^{\circledR} 336$. The organic phase was transferred to $10 \mathrm{~mL}$ of $4 \mathrm{M}$ nitric, mixed using a vortex mixer, and $1 \mathrm{~mL}$ of Aliquat ${ }^{\circledR} 336$ was removed and placed in OPTIMA Gold ${ }^{\mathrm{TM} 3}$ for liquid scintillation counting (LSC). These steps were carried out for the base wash in 4M sodium hydroxide and a second acid wash using 4M nitric acid (see acid-side extraction in Appendix A).

For the base-side extraction, the spiked simulant was subjected to TEVA ${ }^{\circledR}$ resin extraction as well as Aliquat ${ }^{\circledR} 336$ extraction. For the Aliquat ${ }^{\circledR} 336$ extraction samples (S13R000492, -493, and -494), duplicates were taken, and $0.5 \mathrm{~mL}$ of the $54,000 \mathrm{dpm}$ pertechnetate solution was added as the technetium spike. Aliquots of the Aliquat ${ }^{\circledR} 336$ and the TEVA ${ }^{\circledR}$ extractions were transferred to OPTIMA Gold ${ }^{\mathrm{TM}}$ for LSC. Any sample not subjected to LSC was submitted for inductively coupled plasma-mass spectrometry (ICP-MS) analyses (see base-side extraction in Appendix A).

\section{RESULTS}

A sample of the simulant without the pertechnetate spike (S13R000510) was analyzed by ICP-MS, resulting in a less-than value for mass 99. Table 2 presents the results for the Aliquat ${ }^{\circledR}$ 336 cascade of acid and base washings.

Table 2. Results from the Analyses of Aliquat ${ }^{\circledR} 336$ from Acid-Side Extraction.

\begin{tabular}{|l|c|l|c|}
\hline \multicolumn{1}{|c|}{ Sample Number } & Wash & \multicolumn{1}{c|}{ Matrix } & dpm/mL \\
\hline S13R000491 & NA & Spiked Simulant & $\begin{array}{c}17,447 \\
(18,000 \text { expected })\end{array}$ \\
\hline S13R000497 & NA & TEVA $^{(B)}$ Resin & 14,112 \\
\hline S13R000496 & NA & Effluent from TEVA $^{\circledR}$ & $<2.26$ \\
\hline S13R000492 & 4M Nitric Acid & Aliquat ${ }^{\circledR} 336$ & 18,521 \\
\hline S13R000493 & 4M Sodium Hydroxide & Aliquat@ 336 & 17,919 \\
\hline S13R000494 & 4M Nitric Acid & Aliquat ${ }^{\circledR} 336$ & 19,562 \\
\hline S13R000512 & 4M Nitric Acid & 4M Nitric Acid & 177 \\
\hline
\end{tabular}

Table 3 presents the results from the base-side extraction.

\footnotetext{
${ }^{3}$ OPTIMA Gold is a trademark of PerkinElmer Inc., Waltham, MA.
} 
Table 3. Results from the Analyses of Base-Side Extractions.

\begin{tabular}{|l|l|l|c|}
\hline \multicolumn{1}{|c|}{ Sample Number } & \multicolumn{1}{c|}{ Wash } & \multicolumn{1}{c|}{ Matrix } & dpm/mL \\
\hline & NA & Spiked Simulant & 17,447 \\
S13R000499 & NA & TEVA $^{\circledR}$ Resin & $18,000$ expected $)$ \\
\hline S13R000507 & NA & Effluent from TEVA $^{\circledR}$ & $<2.26$ \\
\hline S13R000506 & 4M Nitric Acid & 4M Nitric Acid & 1,056 \\
\hline S13R000503 & 4M Sodium Hydroxide & 4M Sodium Hydroxide & 7.4 \\
\hline S13R000504 & 4M Nitric Acid & 4M Nitric Acid & 891 \\
\hline S13R000505 & Aliquat ${ }^{\circledR} 336$ & Aliquat ${ }^{\circledR} 336$ & 23,913 \\
\hline S13R000508 & & \\
\hline
\end{tabular}

An aliquot of the spiked simulant (S13R000499) was split and subjected to both Aliquat ${ }^{\circledR} 336$ extraction and TEVA ${ }^{\circledR}$ Resin. Table 4 shows the results.

Table 4. Results of Aliquat ${ }^{\circledR} 336$ Extraction and TEVA ${ }^{\circledR}$ Resin.

\begin{tabular}{|l|c|c|}
\hline \multicolumn{1}{|c|}{ Sample Number } & Matrix & dpm/mL \\
\hline S13R000511 & Aliquat ${ }^{\circledR} 336$ & 15,074 \\
\hline S13R000511 & TEVA $^{\circledR 3}$ Resin & 16,399 \\
\hline
\end{tabular}

\section{CONCLUSIONS}

In Phase 1 of this effort, it appears that both Aliquat ${ }^{\circledR} 336$ and TEVA ${ }^{\circledR}$ Resin extract pertechnetate either directly from the highly alkaline sample or from the sample after acidification. In the extraction using $\mathrm{TEVA}^{\circledR}$ Resin, the sample is not subjected to oxidation as occurs with Aliquat ${ }^{\circledR} 336$. When using Aliquat ${ }^{\circledR} 336$, the vortex step used to partition the pertechnetate into the organic will oxidize non-pertechnetate technetium. It also appears that the pertechnetate largely remained with the Aliquat ${ }^{\mathbb{B}} 336$ and did not readily partition in the acid and base washes.

The spiked simulant value of $1.39 \mathrm{E}-02 \mu \mathrm{Ci} / \mathrm{mL}$, as reported by ICP-MS, converts to $17,447 \mathrm{dpm} / \mathrm{mL}$. If this value is taken as a true value and used to calculate percent error by the following equation, the results are as presented in Table 5. The typical request from the Hanford tank farms is for results that are plus or minus $20 \%$ error, while the Resource Conservation and Recovery Act (RCRA) "J" Flag indicates an estimated value.

$$
\% \text { Error }=(\text { Absolute }(\text { True value }- \text { Experimental value }) / \text { True Value }) * 100
$$


Table 5. Percent Error as a Function of Spike Concentration.

\begin{tabular}{|c|c|c|c|c|}
\hline \multicolumn{5}{|c|}{ Acid-Side Extraction } \\
\hline Sample Number & Wash & Matrix & $\mathrm{dpm} / \mathrm{mL}$ & \% Error \\
\hline S13R000491 & NA & Spiked Simulant & 17,447 & NA \\
\hline S13R000497 & NA & TEVA $^{(B}$ Resin & 14,112 & 19.12 \\
\hline S13R000496 & NA & TEVA ${ }^{\mathbb{B}}$ Effluent & $<2.26$ & - \\
\hline S13R000492 & 4M Nitric Acid & Aliquat $\AA 336$ & 18,521 & 6.16 \\
\hline S13R000493 & $\begin{array}{l}\text { 4M Sodium } \\
\text { Hydroxide }\end{array}$ & Aliquat ${ }^{\circledR} 336$ & 17,919 & 2.71 \\
\hline S13R000494 & 4M Nitric Acid & Aliquat $\AA 336$ & 19,562 & 12.12 \\
\hline S13R000512 & 4M Nitric Acid & 4M Nitric Acid & 177 & 98.98 \\
\hline \multicolumn{5}{|c|}{ Base-Side Extraction } \\
\hline Sample Number & Wash & Matrix & $\mathrm{dpm} / \mathrm{mL}$ & \% Error \\
\hline S13R000499 & NA & Spiked Simulant & 17,447 & NA \\
\hline S13R000507 & NA & TEVA $^{(B)}$ Resin & 19,566 & 12.14 \\
\hline S13R000506 & NA & TEVA $^{(B)}$ Effluent & $<2.26$ & \\
\hline S13R000503 & 4M Nitric Acid & 4M Nitric Acid & 1,056 & 93.94 \\
\hline S13R000504 & $\begin{array}{l}\text { 4M Sodium } \\
\text { Hydroxide }\end{array}$ & $\begin{array}{l}\text { 4M Sodium } \\
\text { Hydroxide }\end{array}$ & 7.4 & 99.96 \\
\hline S13R000505 & 4M Nitric Acid & 4M Nitric Acid & 891 & 94.90 \\
\hline S13R000508 & Aliquat $\AA 336$ & Aliquat ${ }^{\circledR} 336$ & 23,913 & 37.06 \\
\hline \multicolumn{5}{|c|}{ S13R000499 Subjected to TEVA $^{\circledR}$ and Aliquat ${ }^{\circledR} 336$} \\
\hline Sample Number & & Matrix & $\mathrm{dpm} / \mathbf{m L}$ & \% Error \\
\hline S13R000511 & NA & Aliquat $\AA 336$ & 15,074 & 13.60 \\
\hline S13R000511 & NA & TEVA $^{(B)}$ Resin & 16,399 & 6.35 \\
\hline
\end{tabular}

Upon inspection of Table 5, several conclusions are readily drawn from the data:

- From the Acid-Side Extraction:

- The pertechnetate did not readily partition into the acid and base washes, and largely remained with the Aliquat ${ }^{\circledR} 336$.

- The TEVA ${ }^{\circledR}$ Resin did capture pertechnetate, based on the effluent analyses which were below detection limits for technetium-99 by ICP-MS analysis. The higher percent error (19.12) was most probably a function of sampling error.

- The high percent error associated with sample S13R000512 is merely an indication that a very small amount of pertechnetate was partitioned at the very last wash step.

- From the Base-Side Extraction:

- The pertechnetate did not readily partition into the acid and base washes, albeit the acid wash was more amenable to partitioning.

- The TEVA ${ }^{\circledR}$ Resin did capture pertechnetate based on the effluent analyses, which were below detection limits for technetium-99 by ICP-MS analysis. The higher percent error (12.14) was most probably a function of sampling error.

- Sample S13R000508 was the LSC analysis of the Aliquat ${ }^{\circledR} 336$ after all washings. The reason for the high percent error may be due to uncertainty 
around the spike recovery (if the spike recovery number is less than the concentration, the sample number will increase), experimental error, operator error, etc.

- Sample S13R000511, processed in duplicate and analyzed by both Aliquat $^{\circledR} 336$ and TEVA ${ }^{\circledR}$ Resin, yielded $13.60 \%$ and $6.35 \%$ error, respectively.

It would appear that the TEVA ${ }^{\circledR}$ Resin is a candidate for the uptake of pertechnetate; it remains to be determined how non-pertechnetate species will behave in the matrix. Figure 3 is a graph from Eichrom showing pertechnetate being fixed for an acidity range between 0.1 to $1 \mathrm{M} \mathrm{H}^{+}$; the pertechnetate is eluted from the resin using $8 \mathrm{M} \mathrm{HNO}_{3}$ (TEVA Resin, [Eichrom 2006]).

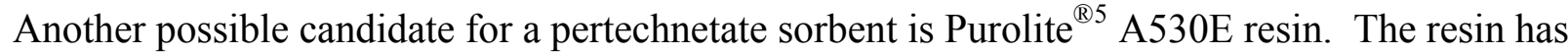
been shown to have a high specificity for pertechnetate, exhibiting a distribution coefficient of $\sim 1150$ at 250 minutes (LAB-RPT-12-00002, Laboratory Report on the Removal of Pertechnetate from Tank 241-AN-105 Simulant using Purolite A530E).

\footnotetext{
${ }^{5}$ Purolite is a registered trademark of Brotech Corporation, Bala Cynwyd, Pennsylvania.
} 
Figure 3. Acid Dependency of k' for Various Ions at $23^{\circ} \mathrm{C}$ on TEVA Resin. ${ }^{1}$ Acid dependency of $\mathrm{k}^{\prime}$ for various ions at $23^{\circ} \mathrm{C}$.
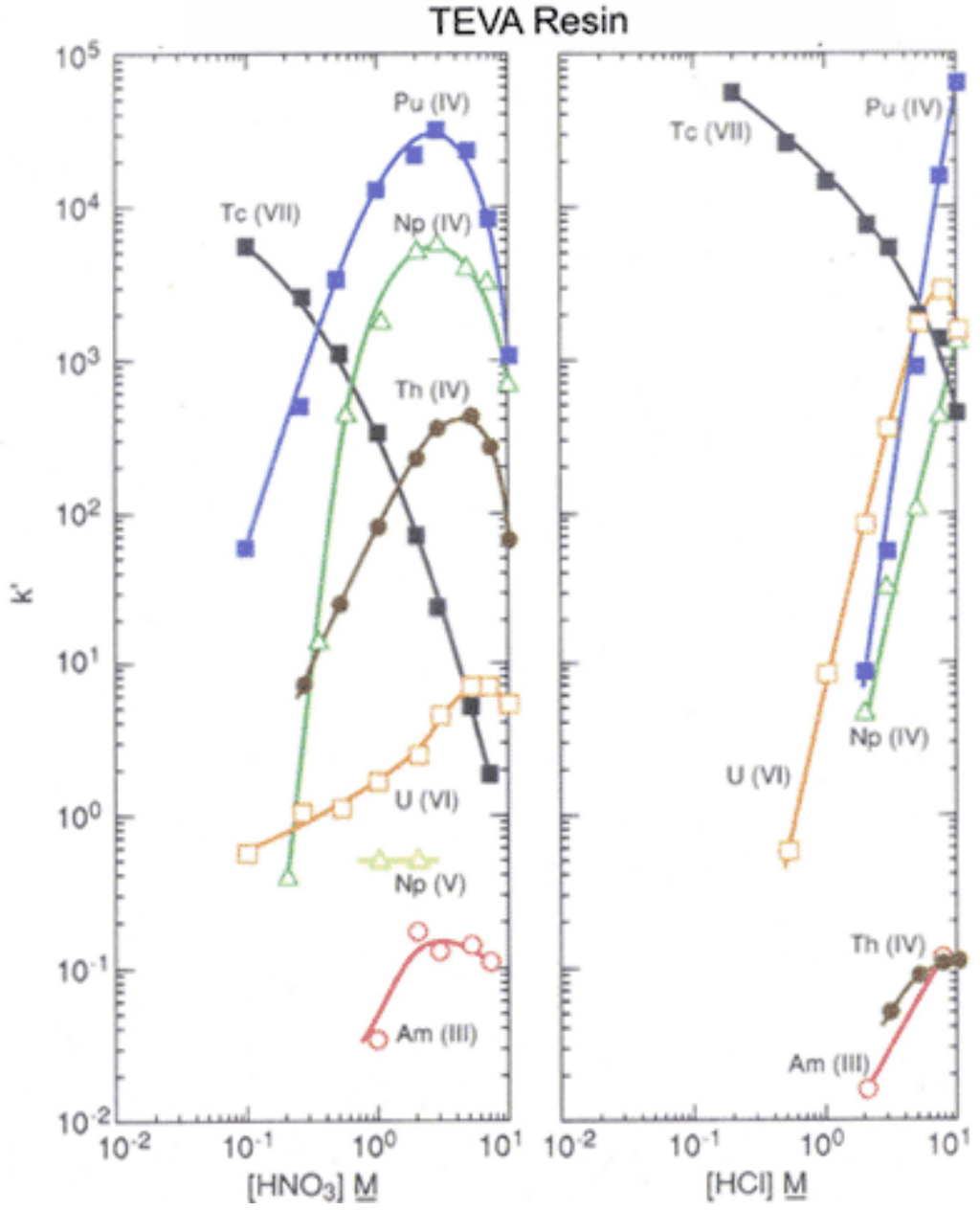

${ }^{1}$ Eichrom 2006 


\section{REFERENCES}

Berning, D. E., N. C. Schroeder, and R. M. Chamberlin, 2005, "The autoreduction of pertechnetate in aqueous, alkaline solutions," Journal of Radioanalytical and Nuclear Chemistry, Vol. 263, No. 3, pp. 613-618.

Eichrom, RadChem Info, No. 6, September, 2006.

LA-438-101, Rev. L-0, 2012, "Determination of Technetium by Solvent Extraction," Advanced Technologies and Laboratories International, Inc., Richland, Washington.

LA-438-114, Rev. A-0, 2012, "Determination of Technetium-99 by Extraction with TEVA Resin,” Advanced Technologies and Laboratories International, Inc., Richland, Washington.

LA-UR-95-4440, 1995, Technetium Partitioning for the Hanford Tank Waste Remediation System: Anion Exchange Studies for Partitioning Technetium from Synthetic DSSF and DSS Simulants and Actual Hanford Wastes (101-SY and 103-SY) Using Reillex ${ }^{T M}-H P Q$ Resin, Los Alamos National Laboratory, Los Alamos, New Mexico.

LAB-PLN-13-00004, 2013, The Determination of Pertechnetate and Non-Pertechnetate Species in Hanford Tanks Phase I, Rev. 0, Washington River Protection Solutions LLC, Richland, Washington.

LAB-RPT-12-00002, 2012, Laboratory Report on the Removal of Pertechnetate from Tank 241-AN-105 Simulant using Purolite A530E, Rev. 1, Washington River Protection Solutions LLC, Richland, Washington.

Landgren, A., J. O. Liljenzin, 1999, "Extraction behavior of technetium and actinides in the Aliquat-336/nitric acid system," Solvent Extraction and Ion Exchange, Vol. 17(6), pp. 1387-1401. 
Attachment A

Sample Breakdown Diagrams 


\section{PERTECHNETATE AND NON-PERTECHNETATE SPECIES}

IN HANFORD TANKS

PHASE 1

$\underline{\operatorname{Rev} 3}$

Customer: RESEARCH

Project: PERTECHNETATE

Group: 20130990

Due:

CACN:

PC: John Trechter

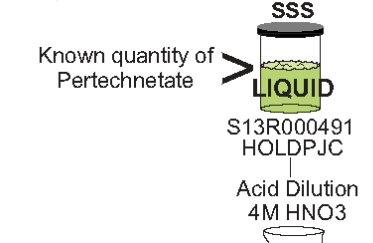

Acid-Side Extraction

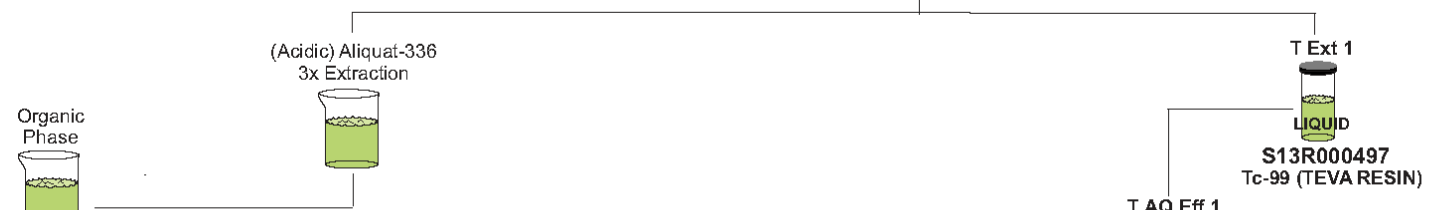

Acid Wash
4M HNO3

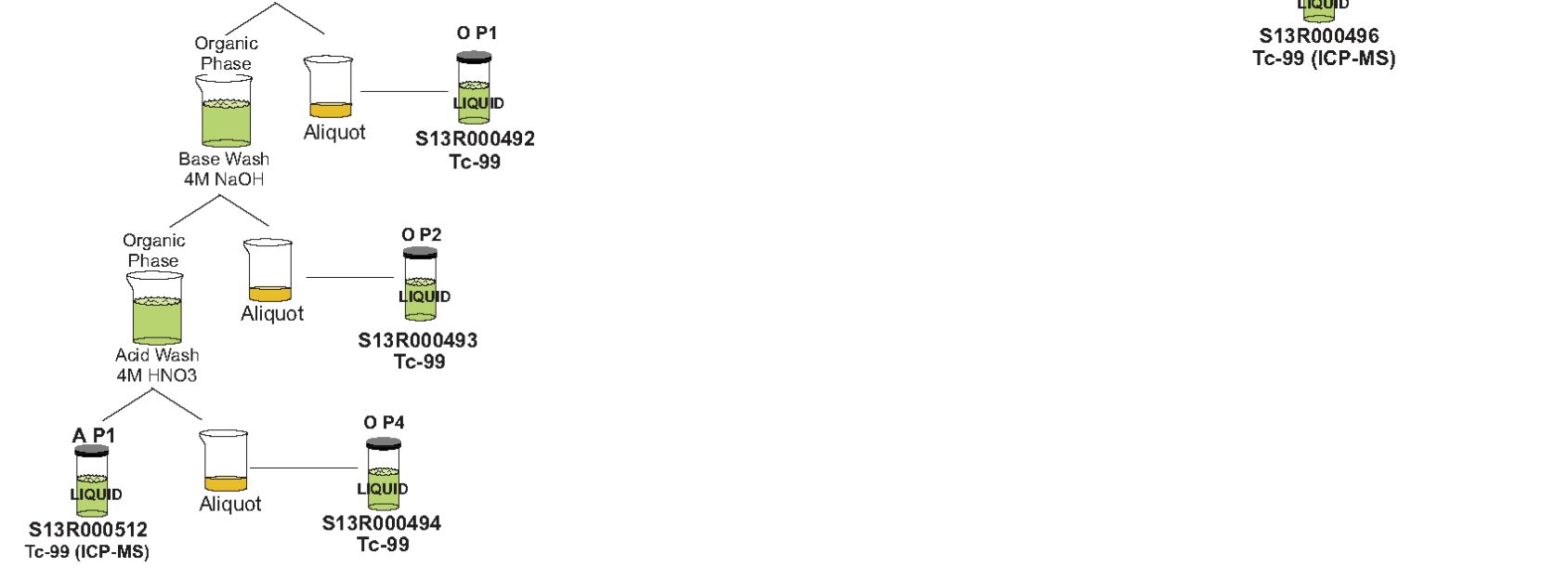

TAQEff

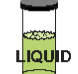

S13R000496

TC-99 (ICP-MS) 


\section{PERTECHNETATE AND NON-PERTECHNETATE SPECIES}

IN HANFORD TANKS

$\underline{\operatorname{Rev3}}$

Customer: RESEARCH

Project: PERTECHNETATE

Group: 20130990

Due:

CACN:

PC: John Trechter

PHASE 1

$\begin{gathered}\text { Known quantity of } \\ \text { Pertechnetate }\end{gathered}>$

SSS $1 T \quad$ S13R000499

TC-99(ICP-MS)

Base-Side Extraction

S13R000511

Tc-99
Tc-99(TEVA)

Baseside Extraction

(Non-Acidic) Aliquat-336

3x Extraction

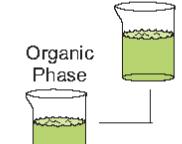

Acid Wash

4M HNO3

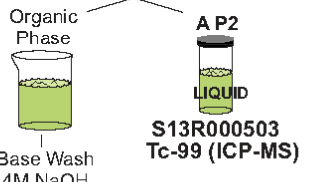

Base Wash

$\stackrel{\text { Phase }}{\text { AP3 }}$

S13R000504

Acid Wash
4M HNO3

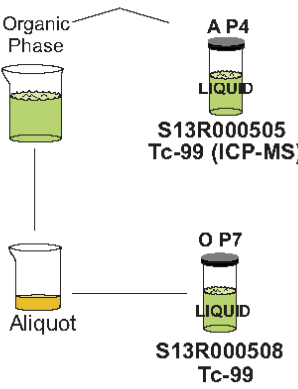

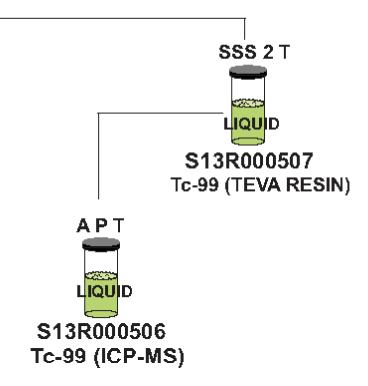




\section{PERTECHNETATE AND NON-PERTECHNETATE SPECIES}

IN HANFORD TANKS

PHASE 1

\section{$\underline{\operatorname{Rev} 3}$}

Customer: RESEARCH

Project: PERTECHNETATE

Group: 20130990

Due:

CACN:

PC: John Trechter

$$
\begin{gathered}
\text { No Added } \\
\text { Pertechnetate }
\end{gathered}>\underbrace{\text { BSSS }}_{\substack{\text { S13R000510 } \\
\text { TC-99(ICP-MS) }}}
$$

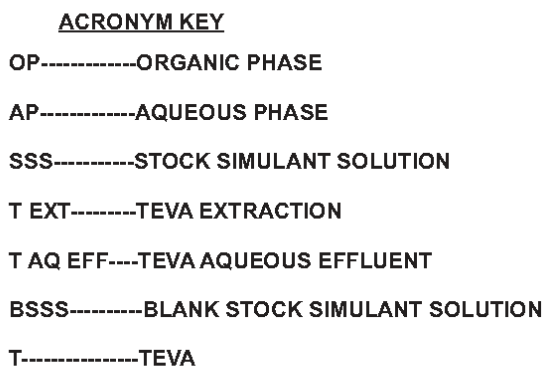




\section{Electronically Approved by:}

UserName: Duncan, James (h0079048)

Title: APD Chemist

Date: Wednesday, 05 February 2014, 10:19 AM Pacific Time

Meaning: Approved by the author or delegate

UserName: Robbins, Rebecca (h0481750)

Title:

Date: Monday, 10 February 2014, 04:51 PM Pacific Time

Meaning: Approved by the customer or delegate

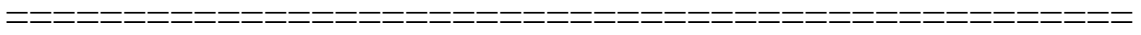

UserName: Cooke, Gary (h0410221)

Title: APD Chemist

Date: Tuesday, 11 February 2014, 10:18 AM Pacific Time

Meaning: Approved by the Group Manager or delegate 
DISTRIBUTION SHEET

\begin{tabular}{|c|c|c|c|}
\hline \multirow[b]{2}{*}{ Distribution } & \multirow[b]{2}{*}{ WRPS Process Chemistry } & \multicolumn{2}{|c|}{ Page $\quad \underline{1}$ of $\underline{1}$} \\
\hline & & Date & $2 / 18 / 2014$ \\
\hline \multicolumn{2}{|l|}{ Project Title/Work Order } & EDT No. & NA \\
\hline \multicolumn{2}{|c|}{$\begin{array}{l}\text { LAB-RPT-13-00009, The Determination of Pertechnetate and Non- } \\
\text { Pertechnetate Species in Hanford Tanks - Phase } 1\end{array}$} & ECN No. & NA \\
\hline
\end{tabular}

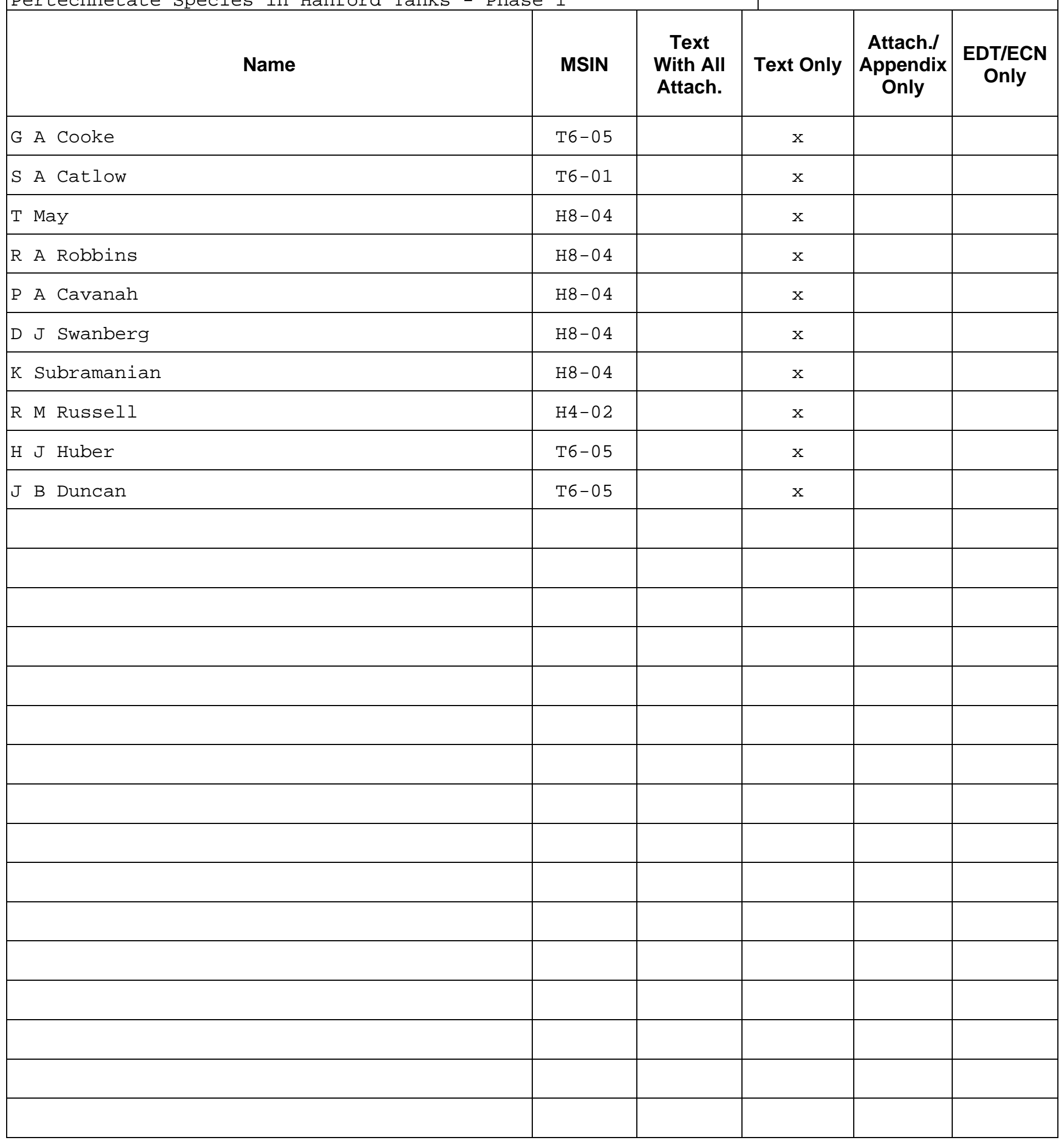

